\title{
THE ANALYSIS OF POTENTIAL RESTAURANT TAX REVENUE IN BANYUWANGI REGENCY
}

\author{
Yeni Puspita, Galih Wicaksono \\ University of Jember \\ yeni.fisip@unej.ac.id, galih.fisip@unej.ac.id
}

\begin{abstract}
Banyuwangi is a regency which promotes tourism sector, shown by several festivals and new tourism destinations. The regency has risen the multiplier effect on other sectors, especially tax revenue. This research aims at investigating the potential of restaurant's tax as a result of improvement in tourism sector and the policy strategy organized by the government in optimizing the income from restaurant's tax. This research was conducted through the survey and interview. This research applied mix method, the result of this research indicate that the potential of restaurant's tax in Banyuwangi is IDR 25.768.142.679. In fact, the target set in 2016 was IDR 7.000.000.000,-. There are several strategies implemented to increase the revenue from the potential taxes of restaurant, inter alia 1) intensive socialization of food to the taxpayer 2) involving other institutions in the implementation of restaurant tax, for example the subdistrict and village, 3) carefully monitoring held on taxpayers, 4) giving some administration and morals sanctions for taxpayers who disobey restaurant's tax regulations, 5) innovation of paying restaurant's tax by online media to facilitate the taxpayer in fulfilling tax obligations.
\end{abstract}

Keywords: Target, Realization, tax potential, restaurant's tax, policy

\section{INTRODUCTION}

National Development aims to create a fair and prosperous society that is materially and spiritually equitable based on the 1945 Pancasila and the Constitution of the Republic of Indonesia. In addition, it endeavours to run the economy and actualize social welfare. National development relies on the State Revenue and Expenditure Budget or the APBN as the main funding source. However, development funding originating from APBN actually oftentimes becomes an obstacle in realizing the national development plan because the State Budget has a limited fund. In the end, the government has to strive to increase state cash revenue from various sectors, both from the State-Owned Enterprises (BUMN) and from the taxation sector. The same thing has happened to local governments. As a consequence of carrying out regional autonomy, every region is required to increase the source of local revenue, so they can finance the government administration and further improve its services to the citizens. Regional Original Revenue (known as $P A D$ ) is all regional revenues originating from regional economic sources. $P A D$ plays an important role in contributing to regional revenue, so it is expected that every region strengthen their economic system (Rochmadika et al., 2015).

Taxes for local governments serve as the main source of revenue and as a regulator. Tax as the source of regional revenue is used to finance regional government expenditures, such as financing government administration, building, and repairing infrastructure, providing education and health facilities, and financing local 
government activities in providing needs which cannot be provided by the private sector, in the form of public goods.

Banyuwangi regency is one of the regencies in East Java which is located on the transit route between Java and Bali. This shows that Banyuwangi Regency is a strategic area to invest and open businesses. One type of local tax with growing potential along with the increase in the recreational or tourism business sector in Banyuwangi regency is restaurant tax. This sector has promising prospects in Banyuwangi regency, which is indicated by an increase in the tourism sector, the following data shows the number of tourist visits, both domestic and foreign tourists, which have continued to increase in the past two years.

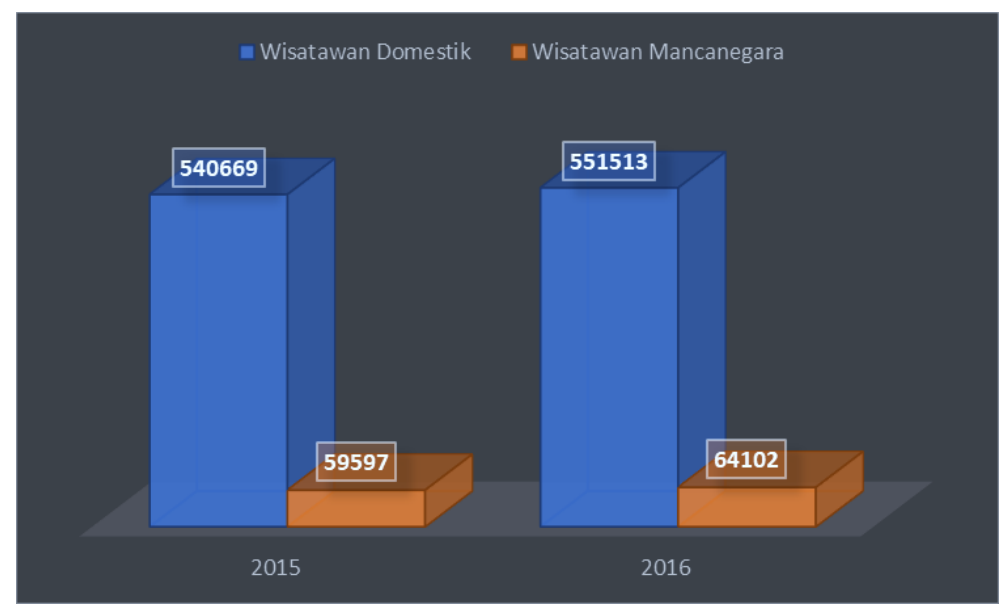

Table 1. The Number of Domestic and International Visits

Source: Banyuwangi in Number (2018)

In recent years, Banyuwangi regency has held several festivals related to the tourism sector and the socio-culture belonging to Banyuwangi regency. The government also has intensively carried out promotional activities introducing several tourist attractions in Banyuwangi regency. Some of these events certainly have made Banyuwangi regency famous and brought in a huge number of tourists visiting Banyuwangi, both domestic and foreign tourists. The increase in tourist arrivals has a substantial effect on the amount of restaurant tax received by Banyuwangi regency. Many local entrepreneurs in Banyuwangi are opening businesses in the restaurant or culinary sector, be it a small, medium, or large scale.

Based on Banyuwangi regency's Regional Medium-term Development Plan (RPJMD) in 2017, the government targeted the number of visitors or tourists from within and outside the country to increase throughout the years. The target for 2017 tourists was 13 million international tourists and 263 million domestic tourists. This becomes a big capital for the regional revenue of Banyuwangi regency. Restaurant tax accounts for the fourth largest value of all types of local taxes administered by Banyuwangi regency, after the tax on road lighting, BPHTB Tax (Customs for Land and Building Rights), and PBB P2 (Rural and Urban Land and Building Taxes). However, the percentage (\%) of its realization is the third largest (three) of the target set, after the ВРНТВ Tax and the Hotel Tax. Therefore, we can conclude that restaurant tax has a 
significant contribution to the revenue of Banyuwangi PAD. However, this increase is not offset by the percentage (\%) of the target and actualization of restaurant tax, which have remained volatile each year. In 2011 , the actualization was $114.50 \%$. However, in 2012 it dropped to only $84.51 \%$. In 2013, it was quite high, reaching $265.44 \%$. However, in 2014 it sank to $132.29 \%$. Furthermore, in 2015 the tax revenue rose to $176.89 \%$.

Table 2. Target and Realization of Restaurant Tax Revenues of Banyuwangi Regency in 2015

\begin{tabular}{|r|r|r|c|}
\hline Year & Target $(\mathbf{R p})$ & Realization $(\mathbf{R p})$ & Percentage (\%) \\
\hline $\mathbf{2 0 1 1}$ & 500.000 .000 & 572.492 .562 & 114,50 \\
\hline $\mathbf{2 0 1 2}$ & 750.000 .000 & 633.839 .278 & 84,51 \\
\hline $\mathbf{2 0 1 3}$ & 774.840 .000 & 2.056 .697 .732 & 265,44 \\
\hline $\mathbf{2 0 1 4}$ & 2.180 .000 .000 & 2.883 .964 .300 & 132,29 \\
\hline $\mathbf{2 0 1 5}$ & 2.800 .000 .000 & 4.953 .007 .419 & 176,89 \\
\hline
\end{tabular}

Source: Regional Revenue Department of Banyuwangi (2016)

Based on the background aforementioned, the researchers deem it important to conduct a study to find out exactly the potential of restaurant tax revenue in Banyuwangi regency and the policy strategies which need to be actualized in optimizing restaurant tax revenue in Banyuwangi regency. Therefore, this study has also aimed to find solutions and answers to several problems in the field relating to the potential of Restaurant Tax revenue in Banyuwangi regency.

Research Problems

Based on the research background aforementioned, the main issues investigated in the study include the followings.

1) Do the restaurant tax target and its realization, according to data from the Banyuwangi Regency Regional Revenue Agency, match the potential of restaurant taxes?

2) What are the policy strategies in optimizing restaurant tax revenue in Banyuwangi regency?

Research Objectives

The study aims at the following objectives.

1) To find out the suitability between the target and realization of restaurant tax according to Banyuwangi Regency Regional Revenue Agency with the potential of real Restaurant Taxes.

2) To find out the right policy strategy in optimizing restaurant tax receipts in Banyuwangi Regency.

\section{LITERATURE REVIEW}

Regional autonomy

Regional autonomy is the right of the people who live in an area to regulate, manage, control, and develop their own businesses by respecting applicable laws and 
regulations (Hanif Nurcholis, 2007). Law Number 32 Year 2004 as amended by Law Number 12 Year 2008 concerning Regional Government also defines autonomous regions as follows. "Autonomous regions, hereinafter referred to as regions, are legal community units which have territorial boundaries authorized to regulate and manage their businesses and the interests of their local community according to its initiative based on the public aspirations in the system of the Unitary State of the Republic of Indonesia".

The benefits of regional autonomy are giving autonomous regions the right to regulate their own regions, so they have the freedom to improve services to their communities. Also, the autonomy makes it easier for autonomous local governments to know or understand the needs of their community. Other benefits of regional autonomy include the following.

1) The implementation of regional autonomy can be carried out according to the public interests.

2) Simplifying complicated bureaucratic pathway and highly structured procedures from the central government.

3) Improving the efficiency of the central government, particularly because central officials no longer carry out routine tasks to the regions due to regional autonomy.

4) Improving supervision in various activities carried out by local elites, who are usually not sympathetic to national development programs and are not sensitive to the needs of poor people in rural area.

5) Increasing the supply of goods and services in an area with affordable and lower costs, eventually making central government off the hook due to regional autonomy.

Regional Original Income based on Law No. 33 of 2004

Based on Law No. 33 of 2004 article 1 verse 15, it is explained that Regional revenue is revenue received from sources within its own territory which are collected based on regional regulations in accordance with applicable legislation. Abdul Halim (2001) points out that Regional Original Income is revenue received by a region from sources within its own territory and collected based on regional regulations in accordance with the existing laws and regulations. From the description abovementioned, it can be concluded that PAD is one part of regional financial income derived from the regional source of incomes which are collected based on legislation to finance the expenses and fulfil their own regional expenditure. The sources of regional income (PAD) as stipulated in Law Number 32 Year 2004 Article 157 involves the following.

Local Tax

Law No. 28 of 2009 elaborates the definition of Regional Tax as a mandatory contribution to the region owed by an individual or entity, which is obligatory in nature, based on the Law. This is obligatory in that there is no direct compensation and 
it is used for regional needs for public welfare. According to Tony Marsyahrul (2004), local taxes are taxes administered by local governments (both Level-1 local government and Level-2 local government). The results are used to finance routine expenses and regional development (APBD), according to Mardiasmo (2002). Tax is compulsory contributions made by individuals or entities to the regions without balanced direct compensation based on the existing laws and regulations, which aims to finance regional government and regional development.

The authority to collect between taxes collected by the provincial government and regency/city governments has numerous differences in their collection. Hereunder are the differences.

1. The authority to collect tax at provincial level lies in the provincial government, while the authority to collect tax at regency/city level lies in the district/city government.

2. The object of the regency city tax is wider than that of the provincial tax. In addition, the object of the regency/city tax can still be expanded based on regional government regulations providing that it does not conflict with the existing provisions. By contrast, the provincial tax, when aiming at expanding tax objects, has to go through law changes.

Banyuwangi Restaurant Tax

According to Banyuwangi Regency Regulation No. 2 of 2011, Restaurant Tax Object is a service provided by restaurants. The purpose of the service provided by the restaurant is selling food and/or drinks consumed by the buyer, consumed both at the service place and elsewhere. The restaurant is not taxed if the service provided by the restaurant does not exceed IDR 1,000,000.00 in a month. Banyuwangi Regency Regulation No. 2 of 2011 stipulates Basic Imposition of Restaurant Tax, the amount of payment which is received or should be received by the restaurant. With respect to the amount of payment, be it unknown and/or deemed to be unnatural, then the imposition of tax is based on the amount of payment received by restaurants. Banyuwangi regency Regulation No. 2 of 2011 stipulates a restaurant tax rate of $10 \%$ (ten percent).

\section{RESEARCH METHODOLOGY}

The study applied quantitative descriptive research, because it was projected to gain the description of the research results published in one analysis. Descriptive method is a method where the researchers will describe research findings. The findings can be pertinent to restaurant taxpayers. After that, it will be compared between the amount of potential, the value of the contribution made by hotel tax and restaurant tax to the Regional Original Income in the Regional Revenue Agency of Banyuwangi regency. The scope under investigation was the sub-district which had a restaurant. The population and research subjects in this study were 287 restaurants spread across 25 sub-districts in Banyuwangi regency, but due to constraints during the survey 
process, there were only 201 restaurants involved in the survey regarding information on potential restaurant taxes.

The analytical method used in this research was quantitative descriptive analysis. Descriptive research deals with collecting data to test hypotheses or answer the final status of the research subjects. Kuncoro (2004) cited in Muhammad (2009) defines quantitative research as research applying mathematical, statistical, or computer models. Thus, quantitative descriptive method aims to describe and point out a problem, situation, or event as it is. The analysis method in the study focused on the calculation of restaurant tax potential by referring to the basic formula of restaurant tax specified in Banyuwangi Regency Regulation No. 2 of 2011.

The calculation method aimed to calculate the average sales turnover per day by using the daily basis frequency, classified into high, medium, and low number of consumers.

$$
\begin{aligned}
& \text { Rata Rata Tertimbang Omzet Penjualan Perhari }=\frac{\sum \text { Jumlah Omzet }}{\sum \text { Hari }} \\
& \begin{aligned}
\sum \text { Jumlah Omzet } & =\text { (Omzet Ramai } X \text { hari ramai })+(\text { Omzet Normal } X \text { hari normal }) \\
& + \text { (Omzet sepi } X \text { hari sepi })
\end{aligned}
\end{aligned}
$$

PPR $($ Tax Potential Calculation $)=$ Average Sales Turnover $X 360$ days $X$ Tax Rates

Turnover is the value of transactions occurring in a count per unit of period, such as daily, weekly, monthly and yearly. Turnover can be said as total gross sales. Calculating turnover in a restaurant business can be done in several ways. These include 1) calculating the number of visitors and the average menu price (the highest price plus the lowest price and divided by two), and 2) calculating the daily sales turnover by multiplying the purchase situation (crowded, medium and quiet).

\section{DISCUSSION}

Potential Restaurant Tax Receipts

By using the PPR or Tax Potential Calculation $=$ Average Sales Turnover X 360 days $X$ Tax Rates, the researchers were able to find out the potential of restaurant tax revenue in each regency. Hereunder are the calculation results.

Table 3. Results of Restaurant Tax Revenue Analysis each Sub-regency of Banyuwangi Regency

\begin{tabular}{|c|l|c|}
\hline No & Sub-Regency & The Potential of Restaurant Tax \\
\hline $\mathbf{1}$ & BANGOREJO & 32.208 .000 \\
\hline $\mathbf{2}$ & BANYUWANGI & 9.909 .147 .621 \\
\hline $\mathbf{3}$ & GAMBIRAN & 3.321 .336 .000 \\
\hline $\mathbf{4}$ & GENTENG & 2.566 .219 .735 \\
\hline $\mathbf{5}$ & GIRI & 290.220 .000 \\
\hline $\mathbf{6}$ & GLAGAH & 579.840 .000 \\
\hline $\mathbf{7}$ & GLENMORE & 499.344 .000 \\
\hline
\end{tabular}




\begin{tabular}{|c|l|r|}
\hline $\mathbf{8}$ & KABAT & 788.064 .000 \\
\hline $\mathbf{9}$ & KALIBARU & 195.000 .000 \\
\hline $\mathbf{1 0}$ & KALIPURO & 2.667 .240 .000 \\
\hline $\mathbf{1 1}$ & LICIN & 544.029 .600 \\
\hline $\mathbf{1 2}$ & MUNCAR & 627.324 .000 \\
\hline $\mathbf{1 3}$ & PESANGGARAN & 171.264 .000 \\
\hline $\mathbf{1 4}$ & PURWOHARJO & 392.368 .800 \\
\hline $\mathbf{1 5}$ & ROGOJAMPI & 2.205 .192 .000 \\
\hline $\mathbf{1 6}$ & SILIRAGUNG & 228.144 .923 \\
\hline $\mathbf{1 7}$ & WONGSOREJO & 751.200 .000 \\
\hline \multicolumn{2}{|c|}{ TOTAL } & 25.768 .142 .679 \\
\hline
\end{tabular}

Based on above calculation, the actual potential of restaurant tax revenue is as follow.

Table 4. Estimate Potential Tax

\begin{tabular}{|c|c|c|c|c|c|c|}
\hline Year & Target & Realization & $\%$ & Effectiveness & Potential & $\begin{array}{c}\text { Estimated } \\
\text { Potential }\end{array}$ \\
\hline $\mathbf{2 0 1 6}$ & 7.000 .000 .000 & 6.898 .991 .797 & 98,56 & Effective & 25.768 .142 .679 & 26,77 \\
\hline
\end{tabular}

The percentage of restaurant tax revenue target in 2016 was $98.56 \%$, which was classified in the effective category. However, the targeted number and realization of restaurant tax was far below the actual potential, which was Rp. 25,768,142,679. Put in other words, that the realization of restaurant tax was only $26.77 \%$ of the potential tax extracted. Therefore, there needs to be a specific strategy in achieving targets and realization to be in accordance with existing potential.

Policy Strategies in Optimizing Restaurant Tax Revenues

Some policy strategies aimed to optimize restaurant tax revenue can be actualized in a number of steps.

1) Strengthen mapping and database compilation with a strong basis on restaurant tax objects which have been registered and potential prospective restaurant tax objects in a sustainable and dynamic manner. This is carried out in the context of calculating restaurant tax potential for several future periods. This aims to find out the number of restaurants in an area in each sub-district. This allows the government to find out how many restaurants have been registered as taxpayers and how many restaurants have not been registered as taxpayers. Furthermore, the data can be used to provide information to taxpayers to take care of restaurant tax obligations. Thus, this information is expected to help increase the amount of restaurant tax.

2) After obtaining an accurate number of restaurant taxpayers in all areas of Banyuwangi regency, then the target of restaurant tax revenue in the future is determined. Consequently, the projection is based on the known potential restaurant tax revenue, which ensures more valid and significant restaurant tax . 
3) There is a need for ongoing socialization to restaurants in all areas of Banyuwangi regency, with the assistance of Sub-regency officials and village/sub-sub regency officials where a restaurant is located. It is also necessary to involve Tourism Office to help collect restaurant taxes in several tourist areas in Banyuwangi regency. Socialization can be done in the form of counseling or distributing brochures or pamphlets that contain restaurant tax regulations.

4) Sanctions in the form of fines or moral sanctions to restaurant taxpayers who violate restaurant tax regulations can be made operative. In addition, it is necessary to give an appreciation to restaurant taxpayers who comply with restaurant tax regulations. As a result, taxpayers will compete to comply with restaurant tax regulations.

5) Increasing and developing infrastructure and facilities to support the realization of prime tax services supported by information technology that reflects transparency. For example, this can be done by creating an information system that enables restaurant taxpayers to find out restaurant tax obligations correctly, clearly and precisely.

6) There is an innovation in restaurant tax payments online. This will make it easier for taxpayers to fulfill their tax obligations. With the online tax payment service, the level of fraud both by the taxpayers concerned and by the apparatus/tax officer is expected to decline.

7) Managing the quality of human resources and increasing the quantity of field staff help to ensure proper and responsible management of restaurant tax.

\section{CONCLUSIONS AND RECOMMENDATIONS}

Based on the discussion related to the mapping of potential restaurant taxes in Banyuwangi regency, the study has drawn the following conclusions.

1. The realization of restaurant tax revenue in Banyuwangi regency in the last six (6) years has met the set targets. This is most likely due to the optimal restaurant tax revenue target. This mapping becomes important to ensure that the revenue becomes more optimal due to the accurate data.

2. In the past five (5) years, restaurant tax revenues in Banyuwangi regency have increased quantitatively every year. This was evidenced by the growth in restaurant tax which increased by $10.71 \%$ in 2012 . This was also corroborated by an increase of $224.48 \%$ in 2013, 40.22\% in 2014, 71.74\% in 2015, and 39.29\% in 2016. This indicates that restaurant tax in the future, when managed properly, will undergo positive trends in the coming years.

3. In general, the potential of restaurant tax in Banyuwangi regency is IDR $25,768,142,679,-$. This figure far exceeds the target set in 2016, which was IDR $7,000,000,000$ and exceeded the realization of restaurant tax in 2016, that was IDR $6,898,991,797$. Simply put, the realization of restaurant tax in 2016 was only $26.77 \%$ of the actual potential. 
4. There are five sub-regencies which are known to be the biggest contributors to restaurant tax revenue in Banyuwangi regency, namely: Banyuwangi sub-regency (38.45\%), Gambiran sub-regency (12.89\%), Kalipuro sub-regency (10.35\%), Genteng sub-regency $(9,96 \%)$, and Rogojampi sub-regency $(8.56 \%)$. Of the five sub-districts, the total contribution reaches $80.21 \%$ of restaurant tax receipts. The remaining $19.79 \%$ is a combination of restaurant tax revenue from 12 other subregencies.

5. In addition to restaurant taxpayer data in Banyuwangi Revenue Agency, the researchers have found that there are still 133 places, comprising of restaurants, cafes, and stalls, which have the potential to become restaurant taxpayers in Banyuwangi regency. This is because some of these places carry out activities which can be subject to restaurant tax. Therefore, these potential places are expected to increase the future pace of restaurant tax growth in Banyuwangi regency.

Based on the discussion relating to the study of the mapping of potential restaurant taxes in Banyuwangi regency, the researchers offer the following recommendations.

1. The Regional Revenue Agency of Banyuwangi Regency in determining the target of restaurant tax revenue should be adjusted to the existing restaurant tax potential. By taking the potential into account, the target setting is expected to be accurate, and it is expected that more optimal restaurant tax realization will be obtained.

2. Banyuwangi Regional Revenue Agency should continuously try to verify restaurant taxpayer data and potential taxpayer candidates in the field within certain timespan. Therefore, restaurant taxpayer data will always be updated and can be taken into consideration prior to determining the apt restaurant tax revenue strategy.

3. It is better to increase the restaurant tax revenue target in accordance with the potential in Banyuwangi regency. This is because the regency's tourism sector has started to develop, implying that the restaurant tax sector will increase significantly.

4. The need for intensive socialization of restaurant taxes to taxpayers, prospective taxpayers, and the general public is unavoidable. Socialization can be done by providing counselling, distributing brochures, and visiting taxpayers and potential taxpayers directly. With intensive socialization, the awareness in the implementation of restaurant taxes is expected to rise.

5. The need to involve other agencies in implementing restaurant taxes needs to be taken into consideration. For example, the regency government involves subdistricts and villages/sub-sub regency where taxpayers are located. Therefore, sub-districts and villages can participate in monitoring restaurant taxpayers in their area. Other agencies that can be involved are the Tourism Office, which plays vital role in the implementation of restaurant taxes located in tourism areas. With 
various parties involved, it is hoped that the effectiveness and efficiency of restaurant tax collection increase.

6. Local tax units need to closely monitor taxpayers, increase the intensity of restaurant tax collection, increase the number of field officers, conduct data and records checking with other agencies related to restaurant management, and improve the tax service system.

7. The administrative sanctions (fines) and morals (social penalties) for taxpayers who do not comply with restaurant tax regulations can be made operative. In the same vein, giving awards to taxpayers who have complied with restaurant tax regulations can encourage more awareness of tax. Therefore, taxpayers will feel proud to be obedient because of the awards given to them.

8. There has to be an innovation in restaurant tax payments through online media. Such innovation will make it easier for taxpayers to fulfil their tax obligations. With the online tax payment service, the level of fraud both by the taxpayers concerned and by the apparatus/tax officer is expected to decline.

9. Technical guidance needs to be done to employees in the area of Regional Revenue Agency, particularly concerned with tax regulations, techniques for optimizing local taxes, or other training that supports increased taxation competence.

10. Based on the mapping of potential restaurant taxes carried out, it turns out that the mapping is able to provide a more accurate picture of the potential for restaurant tax revenue. It is imperative to conduct a survey related to regional tax mapping from other sectors, such as parking tax, boarding tax, and hotel tax. Besides, it is also necessary to conduct a survey relating to regional revenues from regional levies, such as parking fees. This will generate an accurate picture of the potential revenue from regional levies.

\section{REFERENCES}

Abdullah Rozali, 2007, Pelaksanaan Otonomi Luas Dengan Pemilihan Kepala Daerah Secara Langsung. Raja Grafindo Persada. Jakarta.

Deddy Supriady Bratakusmah, Dadang Solihin. 2004. Otonomi Penyelenggaraan Pemerintah Daerah. Jakarta : Gramedia Pustaka.

Hanif Nurcholis. 2007. Teori dan Praktik Pemerintahan dan Otonomi Daerah. Grasindo : Jakarta.

Kaho, Josef Riwu. 2005. Prospek Otonomi Daerah di Negara Republik Indonesia:Identifikasi Faktor-Faktor yang mempengaruhi Penyelenggaraan Otonomi Daerah. Jakarta : PT. Raja Grafindo Persada.

Kesit, Bambang Prakosa.2005. Pajak dan Retribusi Daerah. Yogyakarta: UII Press. 
Kurniawan, Panca, dan Agus Purwanto. 2004. Pajak Daerah dan Retribusi Daerah di Indonesia. Bayumedia : Jakarta.

Mardiasmo. 2008. Perpajakan. Edisi Revisi. Yogyakarta: Andi.

Peraturan Daerah Kabupaten Banyuwangi No 2 Tahun 2011 Tentang Pajak Daerah.

Peraturan Daerah No 14 Tahun 2012 Tentang Perubahan Atas Peraturan Daerah Kabupaten Banyuwangi No 2 Tahun 2011 Tentang Pajak Daerah.

Siahaan P, Marihot. 2008. Pajak Daerah dan Retribusi Daerah. Jakarta: GrafindO

Sugiyono. (2009). Metode Penelitian Bisnis (Pendekatan Kuantitatif, Kualitatif, dan R\&D). Bandung: Alfabeta.

Sunarto. 2005. Pajak dan Retribusi Daerah. Yogyakarta : AMUS dan Citra Pusaka.

Undang-Undang Nomor 28 Tahun 2007 tentang Ketentuan Umum dan Tata Cara Perpajakan.

Undang-Undang Nomor 28 Tahun 2009 tentang Pajak Daerah dan Retribusi Daerah.

Undang Undang Nomor 33 Tahun 2004 tentang Perimbangan Keuangan Pemerintah Pusat dan Daerah.

Widjaja, HAW. 2002. Otonomi daerah dan Daerah Otonom. Jakarta : Raja Grafindo Persada. 